DOI: 10.2478/linpo-2013-0012

\title{
LEXICAL ANAPHORS AND PRONOUNS IN LIANGMAI
}

\author{
MARTIN EVERAERT, KĀRUMŪRI V. SUbBĀRĀO, WiCHAMdinbo MATAINA
}

\begin{abstract}
Martin Everaert, Kārumūri V. Subbārāo, Wichamdinbo Mataina. Lexical Anaphors and Pronouns in Liangmai. Lingua Posnaniensis, vol. LV (2)/2013. The Poznań Society for the Advancement of the Arts and Sciences. PL ISSN 0079-4740, ISBN 978-83-7654-274-4, pp. 41-47.

This paper discusses some aspects of the behavior of anaphors and pronouns in Liangmai, belonging to the Tibeto-Burman language family. We show that Liangmai offers a unique combination of "reflexivization strategies". Like other languages it exhibits the strategy of reflexivizing the predicate by reduplication of an anaphoric element, but it simultaneously marks the predicate with a SELF-element. Two more properties of anaphoric properties of Liangmai are interesting from a cross-linguistic perspective. It shows cases of "swapping" - reordering of differently case-marked elements within the complex anaphor - and long-distance binding - allowing an anaphoric element to refer to an element that is not a co-argument.
\end{abstract}

KEY WORDS: anaphora, case agreement, doubling, long-distance binding, reflexivization

Martin Everaert, University of Utrecht, Department of Languages, Literature and Communication, m.b.h.everaert@uu.nl; Kārumūri V. Subbārāo, University of Hyderabad, India, kvs2811@gmail.com; Wichamdinbo Mataina, Jawaharlal Nehru University, Centre of Linguistics, wichamdin@yahoo.co.in

\section{INTRODUCTION}

In this paper we discuss the behavior of anaphors and pronouns in Liangmai, a TibetoBurman language spoken in Nagaland and Manipur. We do so in the context of the Binding Theory as originated in CHOMSKY 1981. Binding Theory takes the encoding of interpretative dependencies in language, subject to complex syntactic constraints. It is based on a simple distinction between anaphors, subsuming reflexives and reciprocals (cf. (1A)), and pronouns (1B):

(1) A An anaphor (= herself, each other) is bound in its governing category

(1) B A pronominal (= her) is free in its governing category

(1) $\mathrm{C} \quad$ An R-expression is free

Simplifying matters, these conditions state that "anaphors" are referentially dependent on an element that is, basically, a co-argument of the anaphor, while "pronominals" allow any antecedent except a co-argument.

Binding in the syntactic sense of the word is limited to the predicational domain. Reflexives are there for reference in the domain of the clause. Referential dependencies between 
two elements that are not co-arguments is forbidden ground for reflexives - should, in principle, not be observed. However, as frequently noted in a variety of contexts, some anaphors are free in their clause in violation of Condition A (as in JOHN claimed that the queen invited Lucie and HIMSELF for a drink). This phenomenon is called Long-Distance Binding. ${ }^{1}$

In section 2 we describe some prominent, and sometimes unique, properties of reflexives in Liangmai. In section 3 we discuss how some of these properties shed light on recent approaches to binding. Section 4 addresses locality constraints on reflexivization in Liangmai.

\section{SOME PROPERTIES OF LIANGMAI ANAPHORS}

Broadly speaking, one can say that "binding" in all the major languages of South Asia is expressed in terms of either (i) a nominal anaphor (reflexive or reciprocal), or (ii) a verbal anaphor (a verbal clitic/affix, marking reflexivity or reciprocity), or (iii) simultaneous nominal and verbal marking.

\subsection{REFLEXIVIZATION STRATEGIES}

Liangmai has no verbal anaphors; it only has a nominal reflexivization strategy; i.e. the marking of reflexivity occurs in subcategorized positions such as direct object and indirect object. Personal pronouns function as anaphoric elements ${ }^{2}$ in all positions, but in the direct object and indirect object positions this happens in a typologically fairly unique way ${ }^{3}$ (or, so it seems): (i) by reduplication of the personal pronoun and (ii) addition of ronna 'self' to one part of the pronoun, and of the structural case marker (either an accusative or a dative postposition) to the other occurrence. In (2) this is exemplified for the Direct Object (DO) position:

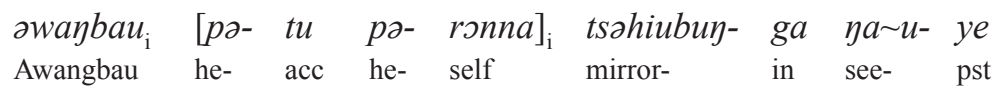

'Awangbau saw himself in the mirror.'

awaybau [pə-ronna pə-tu $]_{\mathrm{i}}$ nkhiu we
awangbou he-self he-AcC wash tense
'Awangbou bathed himself.'

Marking of reflexivity by a doubling strategy is in itself not unique, but it is mostly limited to elements that could be considered an "anaphor". ${ }^{4}$ Take, for instance, the case of Telugu:

$\begin{array}{lllllll}\text { mamata }_{\mathrm{i}} & k i \quad \text { tana mìda tana } & k i & \text { kōpam } & \text { vaccindi } \\ \text { Mamata DAT self on self } & \text { DAT anger came } & \text { com } \\ \text { 'Mamata got angry on/at herself.' } & & & \end{array}$

See discussion in Everaert 2012 on how to define notions such as anaphor, pronominal, and reflexivization.

2 Note that different from traditional use, generative grammar uses the notion "anaphor" for reflexive pronouns and reciprocals. We use both the terms "anaphor" and "anaphoric element".

3 The doubling strategy is mentioned in Dimitriadis \& EVERAERT 2004.

4 Note that Reuland (2011) and Everaert (2012) suggest a pronominal doubling strategy for Bouma Fijian. 
We see in (3) doubling of tana, an element that in its own right could be classified as an anaphor, but definitely not a pronominal, as is the case in Liangmai.

The addition of a SELF-type element in Liangmai, triggering reflexivity, is also not unique, as exemplified by Germanic languages like Dutch (EVERAERT 1986), and English, respectively:

$$
\begin{aligned}
& \text { Ik sprak nooit over *me./mezelf } \\
& \text { I talked never about me/ myself } \\
& \text { 'I never talked about myself.' }
\end{aligned}
$$

She believed $^{*}$ her , $_{\mathrm{i}}$ erself

But the combination of doubling and SELF-marking as found in Liangmai (cf. 2) is, so far, not found in other languages.

\subsection{SWAPPING}

Another rarely observed phenomenon found in Liangmai is that the two parts of the anaphor can be "swapped". Compare (2a), here repeated, with (6):

$$
\begin{aligned}
& \text { zwaybau }_{\mathrm{i}}[\text { pə- tu pə- ronna }]_{\mathrm{i}} \text { tsəhiubuy ga ya u- ye } \\
& \text { Awangbau he- acc he- self mirror in see- pst }
\end{aligned}
$$

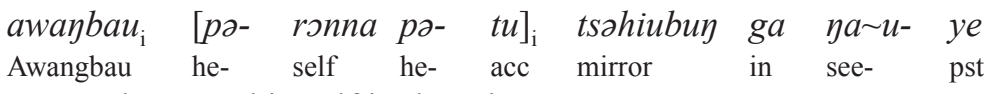

'Awangbau saw himself in the mirror.'

In this respect Liangmai behaves as some Dravidian languages that allow doubled elements to be swapped, as, for instance, the two parts of the Tamil reciprocal (SubBARAO \& EVERAERT 2012):

$$
\begin{aligned}
& \text { avarkal-ukkui oruvar-ai oruvar-ukkui teriy-ā-tu } \\
& \text { they-DAT one.OBL-ACC one.OBL-DAT know-NEG-3SGN } \\
& \text { avarkal-ukkui oruvar-ukkui oruvar-ai.t teriy-ā-tu } \\
& \text { they-DAT one.OBL-DAT one.OBL-ACC know-NEG-3SGN } \\
& \text { 'They don't know each other.' }
\end{aligned}
$$

\subsection{POSSESSIVES}

When a possessive pronoun occurs, it cannot corefer with the subject, see (8):

$$
\begin{aligned}
& \text { namai mathiu pa.pui tu thuan- ye } \\
& \text { child all } \quad \text { his/her.mother acc praise- pst } \\
& \text { 'All the children praised their (not their own) mother.' }
\end{aligned}
$$

However, when the possessive pronoun is reduplicated, it corefers only with the subject. This shows that reduplication plays an important role in anaphoric interpretation: 


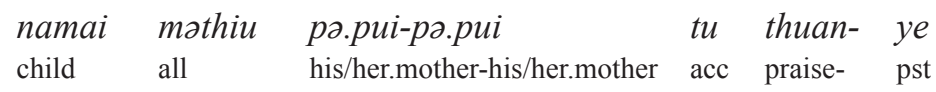

'All the children praised their own mother.'

In (10), a case of inalienable possession, the occurrence of a possessive pronoun either can be interpreted coreferentially with its antecedent or it may have another sentential or discourse antecedent:

$\begin{array}{lllll}\text { awaybau }_{\mathrm{i}} \quad p \mathrm{\partial}_{\mathrm{i}, \mathrm{j}} & \text { th } ₫ \mathrm{~m} \text { ti- } & \text { ye } \\ \text { Awangbau his hair comb- } & \text { PST } \\ \text { 'Awangbau combed his } & \text { hair.' }\end{array}$

This contrasts with other languages which would use a clearly identifiable reflexive, as in Telugu (11a) with a verbal reflexive/self-benefactive, or in Hindi-Urdu (11b) with the form apnā 'self (GEN)':

$\begin{array}{lllllll}\text { pillalu }_{\mathrm{i}} & \left(\text { tama }_{\mathrm{i}}\right) & \text { tala } & \text { duvvu- } & \text { konn- } & \bar{a}- & r u \\ \text { children } & \text { self's } & \text { head } & \text { comb- } & \text { V.refl- } & \text { pst- } & \text { PL }\end{array}$

'The children combed their hair.'

baccõ-ne $_{\mathrm{i}} \quad$ apne $_{\mathrm{i}}$ bāl kārhe
children-ERG self's hair combed
'The children combed their hair.'

\subsection{SUBJECT-OBJECT ASYMMETRY}

A complex anaphor may occur in a non-subcategorized position too, when the subject is the antecedent as in (12):

$$
\begin{aligned}
& \text { swanbau }_{\mathrm{i}} \text { pə.ronna pə.lamga } a_{\mathrm{i}, \mathrm{j}} \text { aliu khu din.khai- ye } \\
& \text { Awanbou he.self he.about we with tell.POLITENESS MARKER- TENSE } \\
& \text { 'Awangbou told us about himself.' }
\end{aligned}
$$

When the subject is the antecedent, the reduplicated form is permitted. However, when an indirect object is the antecedent, a complex anaphor is not permitted as in (13):

$$
\begin{array}{ll}
\text { Jwaybau aliu lamga aliu } u_{\mathrm{i}} k h u \text { din.khai- } & \text { ye } \\
\text { Awangbou we about we with tell.POLITENESS MARKER- } & \text { PAST } \\
\text { 'Awangbou told us about ourselves.' } &
\end{array}
$$

Thus, with regard to antecedency and the occurrence of the complex anaphor, Liangmai shows that there is a Subject-Object Asymmetry. Note that in South Asian languages, especially in Dravidian, there is Subject-Object Asymmetry with regard to the occurrence of the verbal reciprocal (SUBBARAo \& EVERAERT 2012). A verbal anaphor in Dravidian cannot occur when a non-subject is the antecedent.

\section{IDENTITITY DERIVED BY MOVEMENT}

Traditional Binding Theory is formulated in terms of coindexing relationships between argument positions. In the Minimalist Program there is no room for indices (CHOMSKY 1995: 217). Since much of Binding Theory does indeed take indices as theoretical entities, there 
arises the huge task of finding ways to encode anaphoric dependencies with the mechanisms available within the computational system as defined in the Minimalist Program. This means that "identity derived by coindexation" must be replaced by "identity derived by movement". In subsequent work Eric Reuland, among others, explored ways of doing that, culminating in the publication of REULAND 2011.

REULAND (2011) assumes that there are two properties at the basis of licensing reflexivity and reciprocity:

(14) $\mathrm{i} \quad$ A feature deficiency leading to a local binding requirement

(14) ii Creating morphological complexity to avoid violation of the Inability to Distinguish Indistinguishables (IDI)

(14i) is exemplified in an example such as (15):

Hans $_{\mathrm{i}}$ sah $_{\text {sich }}$

'Hans saw himself.'

The German reflexive sich is marked for person (and Case), but not for number and gender. According to Reuland, this feature deficiency is the trigger of the binding relation - feature checking - between object and subject. The case copying mechanism in reciprocal constructions visible in Telugu (16)-(17) and Manipuri (18) is a similar example of this phenonemon (SUBBARAO 2012: 89-90): ${ }^{5}$

$$
\begin{array}{lll}
\text { vāllu okalla-ni okallu } & \text { poguḍu-konn-ā-ru } \\
\text { they.NOM one.PL-ACC one.PL.NOM } & \text { praise-VRECIPROCAL-PST-3PL } \\
\text { 'They praised each other.' } &
\end{array}
$$

$$
\begin{aligned}
& \text { vālla-ki okalla-tō okalla-ki sarigga pad-a-du } \\
& \text { they-DAT one.PL-with one-DAT well get.along-NEG-3sG.NM } \\
& \text { 'They don't get along well with each other.' }
\end{aligned}
$$

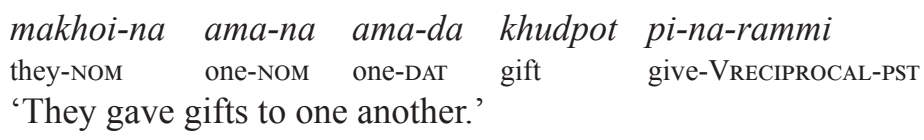

Out of the two 'one's available, one takes the case of the position and the other is casedeficient. The case-deficiency triggers an agreement relation with the subject, manifested as case-agreement: nominative in (16) and dative in (17) and (18). Note that in Telugu the second 'one' takes case-agreement, while in Manipuri it is the first 'one' that agrees in case with the subject. ${ }^{6}$

Reuland's principle (14ii) is the basis of why the English reflexive is a combination of pronoun + self $($ him + self $):{ }^{7}$ Morphological complexity allows a pronoun to be locally

5 Ao and Mao exhibit a similar case copying mechanism (field notes K.V. Subbarao).

6 Note that principle (14i) may not always hold, as in many Tibeto-Burman languages such as Angami (Tenyidie) where the pronoun and the nominal reflexive are homophonous.

$$
\begin{aligned}
& \text { abuno -e puo khie-ki nu tinhy pиo } z u \text { lie } \\
& \text { Abuno- ERG her near-place from snake one see self.BEN } \\
& \text { 'Abuno saw a snake near herself.' }
\end{aligned}
$$

7 We are skipping over many details. 
bound. Likewise, according to Reuland, the doubling strategy (Caxur, Telugu, etc.) creates the morphological complexity to allow local binding. In some cases, doubling is accompanied by case-agreement, as in Tamil (7)-(8), Telugu (16)-(17), and Manipuri (18).

Liangmai is interesting because it combines pronoun doubling (in itself creating morphological complexity), not by case-agreement, but by a second strategy creating complexity, namely adding a SELF-element. This latter strategy is also applied in the case of inalienable possessives. To avoid ambiguity in these cases, an emphatic (pronoun + SELF-element) ${ }^{8}$ is used, as in (19):

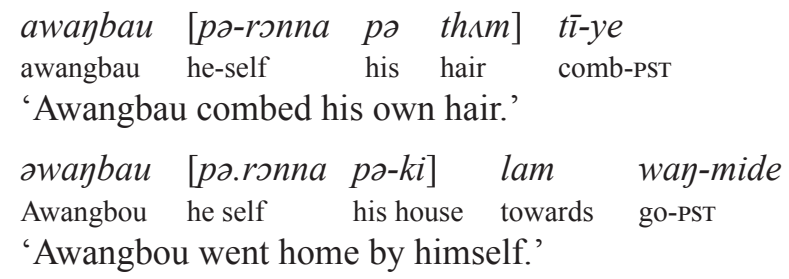

As predicted by (14ii), the addition of the emphatic po-ronna in (19)-(20) disallows deictic binding.

\section{LONG-DISTANCE BINDING}

Long-Distance Binding is generally blocked when the anaphor is complex. Only simplex forms permit this type of binding. This also holds true for Liangmai: ${ }^{9}$

$\begin{array}{llllll}\text { swaybau }_{\mathrm{i}} & \text { niu } & \text { pole }_{\mathrm{i}} & \text { tsa } & \text { toliu } & \text { khai.ra } \\ \text { Awangbou } & \text { erg } & \text { he.for } & \text { tea } & \text { make } & \text { POLITENESS MARKER.to } \\ \text { kariyliu } & \text { tu } & \text { lay- } & \text { ye } & & \\ \text { Karingliu } & \text { acc } & \text { ask- } & \text { PST } & & \end{array}$

'Awangbou asked Karingliu to make tea for him.'

2waybau niu karigliu $_{\mathrm{i}}$ tu pə.ronna
Awangbou

'Awangbou asked Karingliu to prepare a tea for herself.'

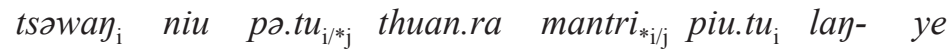

king ERG he.ACC praise to minister CL.ACC ask- TENSE

'The king asked the minister to praise him (king).'

$\begin{array}{lllllll}\text { tsaway } & \text { niu } & \text { mantri }_{\mathrm{i}} & \text { piu.tu }_{\mathrm{i}} & \text { thuan.ra } & \text { məniu- } & \text { ye } \\ \text { king } & \text { ERG } & \text { minister } & \text { CL.ACC } & \text { praise to } & \text { ask- } & \text { TENSE }\end{array}$

'The king asked the minister to praise himself (minister).'

8 pə.rənna 'he/she.self' also functions like an emphatic, just as in most Tibeto-Burman languages and in many other languages of the world. When the form ronna 'self' occurs alone, without a pronoun preceding it, it has the interpretation of 'alone':

$$
\begin{aligned}
& \text { aliu ronna kam- ne } \\
& \text { we alone work- FUT } \\
& \text { 'We'll do it alone.' }
\end{aligned}
$$

9 Note that the light verb $p i$ ' let' in (24) is optional, indicated by parentheses. 


$$
\begin{aligned}
& \text { [əwaybau- niu }]_{\mathrm{i}} \text { rampibau }_{\mathrm{j}} \text { tu (pi) pə.tu } \mathrm{i}_{\mathrm{i}, \mathrm{j}} \text { thuan.ra məniu- ye } \\
& \text { Awangbou ERG Rampibou ACC let/cause he.ACC praise to ask- PST } \\
& \text { 'Awangbou asked Rampibou to praise him (Awangbou, Rampibau).' }
\end{aligned}
$$

To avoid ambiguity the word order of (24) can be changed and pə.tu 'he.ACC' is placed immediately to the right of its potential antecedent Awangbou, resulting in (25):

$\begin{array}{llllll}\text { awaybau }_{\mathrm{i}} \text { niu } & \text { pə.tu } \\ *_{\mathrm{i}, \mathrm{j}} & \text { thuan.ra rampibau } & \text { tu məniu- } & \text { ye } \\ \text { Awangbou ERG he.ACC } & \text { praise to Rampibou ACC ask- } & \text { PST } \\ \text { 'Awangbou asked Rampibou to praise him (Awangbou only).' }\end{array}$

\section{CONCLUSION}

We have discussed some of the basic aspects of reflexivization strategies in Liangmai and have pointed to some of the consequences these facts have for linguistic theorizing. Clearly more detailed work needs to be done, preferably in relation to some closely related languages, in order to get a better understanding of some of the interesting aspects of the grammar of Liangmai.

\section{REFERENCES}

Brown Dunstan, Chumakina Marina, Corbett Greville (eds.). 2012. Canonical Morphology \& Syntax. Oxford: Oxford University Press.

Сномsку Noam. 1981. Lectures on Government and Binding. Dordrecht: Foris.

CHомsкy Noam. 1995. The Minimalist Program. Cambridge, MA: MIT Press.

Comrie Bernard, Suinkonen Pirkko (eds.). 2004. Proceedings of the International Symposium on Deictic Systems and Quantification in Languages Spoken in Europe and North and Central Asia. Izhevsk (Russia): The Udmurt State University.

Dimitriadis Alexis, Everaert Martin. 2004. “Typological Perspectives on Anaphora.” In: Comrie et al. 2004: $51-67$.

Everaert Martin. 1986. The Syntax of Reflexivization. Berlin: Mouton de Gruyter (Foris Publications).

EVERAert Martin. 2012. “The Criteria for Reflexivization.” In: Brown et al. 2012: 190-206.

Reuland Eric. 2011. Anaphora and Language Design. Cambridge, MA: MIT Press.

Reuland Eric, Everaert Martin. 2010. "Reaction to: 'The Myth of Language Universals and cognitive science' - Evans and Levinson's cabinet of curiosities: Should we pay the fee?”. Lingua 120(12), 2713-2716.

Subbarao K.V. 2012. South Asian Languages: A Syntactic Typology. Cambridge: Cambridge University Press. Subbarao K.V., Everaert Martin. 2012. Case Copying and Case Percolation in Polymorphemic Reciprocals in Dravidian: Some Unique Phenomena. Paper presented at the FASAL 2 Conference, Massachusetts Institute of Technology. 